REPORTS OF MORPHOLOGY
$\begin{gathered}\text { Official Journal of the Scientific Society of Anatomists, } \\ \text { Histologists, Embryologists and Topographic Anatomists } \\ \text { of Ukraine } \\ \text { journal homepage: https://morphology-journal.com }\end{gathered}$

\title{
Lumbar intervertebral disks: morphometric parameters and indices
}

\section{Danylevych V.P.', Guminskyi Yu.Y.1, Hryhorieva O.A. ${ }^{2}$, Danylevych S.H. ${ }^{3}$}

${ }^{1}$ National Pirogov Memorial Medical University, Vinnytsya, Ukraine

2Zaporizzhya State Medical University, Zaporizzhya, Ukraine

${ }^{3}$ Medical radiological center, Vinnytsia, Ukraine

\section{ARTICLE INFO}

Received: 26 February 2021

Accepted: 19 April 2021

UDC: 611.721 .1

\section{CORRESPONDING AUTHOR}

e-mail: vidanlet@gmail.com Danylevych V.P.

\begin{abstract}
An important element of evidence-based medicine is to take into account the individual variability of the indicators of the norm of intervertebral discs, which is undoubtedly the basis for early preclinical detection of their pathology. Mathematical modeling and comprehensive assessment of the parameters of the intervertebral discs can not only predict and determine the early manifestations of pathological changes, but also help to correct them in advance. The aim of the study was to calculate and evaluate the variability of absolute, calculated and relative metric parameters of intervertebral discs in the norm with the subsequent possibility of modeling standards based on individual linear dimensions of intervertebral discs of the lumbar spine and general anthropometric characteristics (body length and weight) in young men and men of the first period of adulthood (17-28 years), both in separate age groups and in the combined group. The series of MRI scans obtained on a Phillips Achieva 1.5T scanner measured the anterior, middle and posterior vertical dimensions, maximum sagittal and frontal dimensions of the intervertebral discs L1-L2, L2-L3, L3-L4, L4-L5 segments of the spine (IVD $\left.I V D_{L 2-\angle 3}, I V D_{L 3-L 4}, I V D_{L 4-\angle 5}\right)$. We calculated the average height of the intervertebral discs, cross-sectional area and volume of intervertebral discs, as well as relative indicators - the ratio of the sum of sagittal and transverse dimensions, the sum of three dimensions, cross-sectional area and volume of intervertebral discs to the average intervertebral disc height. Statistical analysis of the obtained morphometric parameters was performed in the license package "STATISTICA 6.1". The distribution of variation series indicators, their average values and standard errors, coefficients of variation and asymmetry were evaluated. It was determined that the sums of the transverse and sagittal sizes and the sums of the three sizes increase proportionally in the caudal direction, have a distribution of indicators as close as possible to normal, and their coefficients of variation are many times smaller than for cross-sectional areas and volumes. Indicators of the ratio of the sum of the sagittal and transverse size and the sum of the three sizes to the average height of the intervertebral discs have a variability of less than $10 \%$ and correspond to the characteristics of the general population. Body weight and length have significantly higher correlation coefficients with the sums of sagittal and transverse dimensions, the sums of three dimensions and cross-sectional areas than with the partial dimensions of the intervertebral discs.

Keywords: intervertebral disc, lumbar spine, norm, somatometry, young men, men of the first period of adulthood.
\end{abstract}

\section{Introduction}

Musculoskeletal pathology, according to the World Health Organization, ranks fourth among the causes of disability and mortality in the world [4, 21]. About $20 \%$ of people suffer from temporary or permanent back pain. Diseases of the musculoskeletal system are also one of the most common problems in Ukraine [5, 22], where about 3.5 million people have problems with the musculoskeletal system and their

neurological complications [16, 20]. Degenerative changes of the spine are an insidious pathology that carefully hides the symptoms of other diseases, which greatly complicates their diagnosis, especially in the early stages of the disease. Despite the fact that the gradual degeneration of the intervertebral disc is considered a natural process that progresses with age, in recent decades the frequency of 
clinical manifestations of these changes in young people is steadily increasing $[1,17]$.

The leading place in development of a degenerative cascade and disturbance of biomechanics of functional segments is occupied by degenerative changes of intervertebral disks. Chondrosis, osteochondrosis, spondylosis, and in the English literature - degenerative disc disease (DDD) $[9,13,23,30]$ - are the most common terms used to denote diseases of the spine, which, to some extent, reflect the most common morphological basis of this pathology.

The use of only averaged values as indicators of the norm does not take into account individuality and can be a factor in misinterpretations of the results.

Despite the urgency of the problem of pathology of the spine both in the world and in Ukraine, a small number of scientific papers of domestic scientists are devoted to this topic, in particular the detection of pathology at an early stage.

In medical practice, morphometric parameters of intervertebral discs, such as sagittal, transverse and vertical dimensions of intervertebral discs, cross-sectional area, volume are not widely used, but only as single studies are found in the scientific literature [8, 27, 29]. Average and generalized criteria for assessing the norm do not take into account the individual characteristics of each human body. Methods using mathematical modeling and methods of comprehensive assessment of the parameters of the intervertebral discs will identify pathological changes in the early stages, and, consequently, to correct them in advance. The use of more criteria for assessing the condition of the intervertebral disc will allow the application of the principles of evidence-based medicine in determining changes in the intervertebral disc and bring the indicators closer to the individual.

However, it should be noted that the use of a full-scale anthropometric study with the measurement of linear and circumferential dimensions is complex and is not widely used in clinical practice. Therefore, the search for simplified mathematical models and a set of relative indicators that are based on a smaller number of initial parameters and as close as possible in accuracy is a priority.

The purpose of the study is to assess the scattering characteristics (variability) of absolute, calculated and relative metric features of intervertebral discs in the norm with the subsequent possibility of modeling standards based on individual linear dimensions $I V D_{\text {L1-L2 }}, I V D_{L_{2}-L 3}, I V D_{L 3-L 4}, I V D_{L 4-L 5}$ and general characteristics (length and body weight, weightgrowth coefficient and index) in young men and men of the first period of adulthood (17-28 years) both in separate age groups and in the combined group.

\section{Materials and methods}

The study involved 74 young men and men aged 17 to 28 years without clinical signs of spinal diseases. They underwent an anthropometric examination to determine the total parameters (length and body weight), performed
MR tomography of the lumbar spine. MRI was performed on a 1.5T scanner (Phillips Achieva 1.5T, Phillips, the Netherlands). MRI scans of the lumbar spine were obtained in the axial, sagittal and frontal planes using T2-weighted turbo-spin-echo sequences.

The obtained MR images were used for further morphometry of intervertebral discs L1-L2, L2-L3, L3-L4, L4-L5 segments of the lumbar spine: measurement of maximum sagittal and frontal dimensions; anterior, middle and posterior vertical sizes of intervertebral discs. Calculated the average height of the intervertebral discs (as the arithmetic mean of the anterior, middle and posterior heights); calculated the cross-sectional areas and volumes of intervertebral discs, as well as relative indicators - the ratio of the sum of sagittal and transverse dimensions, the sum of three dimensions, cross-sectional area and volume of intervertebral discs to the average height of the intervertebral disc.

Statistical analysis was performed in the license package "STATISTICA 6.1". The mean values of the variation series, standard deviations, coefficients of variation and asymmetry, paired t-test, d-test of the Kolmogorov-Smirnov type, Levene's index were evaluated [12, 24, 25].

\section{Results}

The coefficient of variation of the front heights (Table 1) in all age groups had average values of variability in the range from $11.40 \%$ to $17.58 \%$. The highest frequency for indicators of anterior height of all groups is in the range of 2 sigma from $65.79 \%$ to $78.85 \%$ of the total number of observations. When using the paired t-test (Table 2), it was determined that no significant differences in the mean values of the indicators in the groups were determined ( $p>0.05)$. The difference between the mean values in the samples for $I_{\text {IVD }}{ }_{\text {L1-L2 }}$ is $0.327 \mathrm{~mm}$ and $0.447 \mathrm{~mm}$, for IVD $\mathrm{LD}_{\mathrm{L}-\mathrm{L} 3}-0.222 \mathrm{~mm}$ and $0.304 \mathrm{~mm}$, for $I V D_{L 3-L 4}-0.304 \mathrm{~mm}$ and $0.087 \mathrm{~mm}$, for $\mathrm{IVD}_{\text {L4-L5 }}-0.009 \mathrm{~mm}$ and $0.013 \mathrm{~mm}$.

The highest frequency for the mean height of all groups is in the range of 2 sigma from $57.78 \%$ to $78.95 \%$ of the total number of observations. The coefficients of variation (see Table 1) have values close to low variability $(\leq 10)$ - from $8.38 \%$ to $12.37 \%$. When using the paired t-test (see Table 2 ), it was determined that no significant differences in the mean values of the indicators in the groups were determined $(p>0.05)$. The difference between the mean values in the samples for $I V D_{L_{1}-\mathrm{L} 2}$ is $0.327 \mathrm{~mm}$ and $0.447 \mathrm{~mm}$, for $I V D_{\mathrm{L} 2 \mathrm{~L} 33}$ - $0.222 \mathrm{~mm}$ and $0.304 \mathrm{~mm}$, for IVD $\mathrm{LB}_{\text {L-L4 }}-0.304 \mathrm{~mm}$ and $0.087 \mathrm{~mm}$, for IVD $\mathrm{L} 4 \mathrm{~L} 5-0.009 \mathrm{~mm}$ and $0.013 \mathrm{~mm}$.

The coefficients of variation (see Table 1 ) of the posterior vertical dimensions have average values of variability $(\leq 10)$ - from $12.46 \%$ to $15.74 \%$. The highest frequency for the indicators of the posterior height of all groups is in the range of 2 sigma from $57.89 \%$ to $73.68 \%$ of the total number of observations. When using a paired t-test (see Table 2), a significant difference between the mean values for $I V D_{L 1-L 2}$; for $I V D_{L 2-L 3}, I V D_{L 3-L 4}, I V D_{L 4-L 5}(p>0.05)$ significant differences 
in the mean values of the indicators were not detected. The difference between the mean values in the samples for $\mathrm{IVD}_{\mathrm{L} 1-\mathrm{L} 2}$ is $0.432 \mathrm{~mm}$ and $0.591 \mathrm{~mm}$, for $\mathrm{IVD}_{\mathrm{L} 2 \mathrm{-L} 3}-0.244 \mathrm{~mm}$ and $0.333 \mathrm{~mm}$, for IVD $\mathrm{LB}_{\mathrm{L} 4}-0.132 \mathrm{~mm}$ and $0.181 \mathrm{~mm}$, for $\mathrm{IVD}_{\mathrm{L} 4 \mathrm{LL} 5}-0.004 \mathrm{~mm}$ and $0.006 \mathrm{~mm}$.
Transverse dimensions of intervertebral discs IVD ${ }_{\text {L1-L2 }}$, $I V D_{L 2-L 3}, I V D_{L 3-L 4}, I V D_{L 4-L 5}$ of the lumbar spine in these age groups have coefficients of variation (see Table 1) less than $10 \%$ - from $4.66 \%$ to $6.49 \%$, which corresponds to the weak variability of the trait. The highest frequency for

Table 1. Characteristics of intervertebral disks sizes groups $I V D_{L 1-L 2}, I V D_{L 2-L 3}, I V D_{L 3-L 4}, I V D_{L 4-L 5}$ of lumbar spine.

\begin{tabular}{|c|c|c|c|c|c|c|c|}
\hline \multirow{2}{*}{$\begin{array}{l}\text { Intervertebral discs } \\
\text { sizes }\end{array}$} & \multirow{2}{*}{ IVD } & \multicolumn{2}{|c|}{ Young men (17-21 years) } & \multicolumn{2}{|c|}{ Men (22-28 years) } & \multicolumn{2}{|c|}{ Combined group (17-28 years) } \\
\hline & & $\mathrm{M} \pm \mathrm{SD}(\mathrm{mm})$ & Cv\% & $\mathrm{M} \pm \mathrm{SD}(\mathrm{mm})$ & Cv\% & $\mathrm{M} \pm \mathrm{SD}(\mathrm{mm})$ & Cv\% \\
\hline \multirow{4}{*}{ Anterior height } & L1-L2 & $7.949 \pm 0.920$ & 11.57 & $7.370 \pm 1.296$ & 17.58 & $7.705 \pm 1.125$ & 14.60 \\
\hline & L2-L3 & $8.667 \pm 1.150$ & 13.27 & $8.647 \pm 1.254$ & 14.51 & $8.658 \pm 1.188$ & 13.73 \\
\hline & L3-L4 & $9.230 \pm 1.058$ & 11.40 & $9.580 \pm 1.537$ & 16.05 & $9.407 \pm 1.283$ & 13.64 \\
\hline & L4-L5 & $9.803 \pm 1.364$ & 13.92 & $10.38 \pm 1.49$ & 14.34 & $10.04 \pm 1.44$ & 14.32 \\
\hline \multirow{4}{*}{ Average height } & L1-L2 & $10.04 \pm 0.92$ & 9.198 & $9.263 \pm 1.146$ & 12.37 & $9.711 \pm 1.087$ & 11.20 \\
\hline & L2-L3 & $11.03 \pm 0.95$ & 8.613 & $10.51 \pm 1.22$ & 11.66 & $10.81 \pm 1.10$ & 10.17 \\
\hline & L3-L4 & $11.48 \pm 0.96$ & 8.378 & $11.33 \pm 1.22$ & 10.77 & $11.42 \pm 1.07$ & 9.410 \\
\hline & L4-L5 & $11.74 \pm 1.10$ & 9.384 & $11.72 \pm 1.33$ & 11.37 & $11.73 \pm 1.20$ & 10.21 \\
\hline \multirow{4}{*}{ Posterior height } & L1-L2 & $7.182 \pm 0.932$ & 12.98 & $6.159 \pm 0.921$ & 14.95 & $6.750 \pm 1.053$ & 15.60 \\
\hline & L2-L3 & $7.407 \pm 0,923$ & 12.46 & $6.830 \pm 1,037$ & 15.18 & $7.163 \pm 1.009$ & 14.08 \\
\hline & L3-L4 & $7.395 \pm 1.059$ & 14.33 & $7.082 \pm 1.031$ & 14.55 & $7.263 \pm 1.053$ & 14.50 \\
\hline & L4-L5 & $7.270 \pm 1.077$ & 14.82 & $7.280 \pm 1.146$ & 15.74 & $7.274 \pm 1.100$ & 15.13 \\
\hline \multirow{4}{*}{ Transverse size } & L1-L2 & $51.64 \pm 2.77$ & 5.371 & $49.86 \pm 3.24$ & 6.492 & $50.89 \pm 3.09$ & 6.071 \\
\hline & L2-L3 & $53.67 \pm 2.69$ & 5.007 & $52.48 \pm 3.33$ & 6.341 & $53.16 \pm 3.01$ & 5.670 \\
\hline & L3-L4 & $55.32 \pm 2.58$ & 4.659 & $54.71 \pm 3.43$ & 6.274 & $55.06 \pm 2.97$ & 5.386 \\
\hline & L4-L5 & $56.90 \pm 2.83$ & 4.965 & $56.03 \pm 3.53$ & 6.300 & $56.53 \pm 3.15$ & 5.577 \\
\hline \multirow{4}{*}{ Sagittal size } & L1-L2 & $38.05 \pm 2.45$ & 6.427 & $37.06 \pm 2.62$ & 7.078 & $37.63 \pm 2.56$ & 6.791 \\
\hline & L2-L3 & $39.52 \pm 2.18$ & 5.510 & $38.43 \pm 2.56$ & 6.667 & $39.06 \pm 2.40$ & 6.133 \\
\hline & L3-L4 & $39.75 \pm 2.03$ & 5.114 & $38.81 \pm 3.02$ & 7.774 & $39.35 \pm 2.52$ & 6.413 \\
\hline & L4-L5 & $41.37 \pm 2.05$ & 4.943 & $40.50 \pm 3.31$ & 8.145 & $40.99 \pm 2.67$ & 6.502 \\
\hline \multirow{4}{*}{$\begin{array}{l}\text { The average value of } \\
\text { the height }\end{array}$} & L1-L2 & $8.389 \pm 0.740$ & 8.818 & $7.598 \pm 0.893$ & 11.75 & $8.055 \pm 0.894$ & 11.10 \\
\hline & L2-L3 & $9.035 \pm 0.742$ & 8.208 & $8.661 \pm 0.920$ & 10.62 & $8.877 \pm 0.838$ & 9.435 \\
\hline & L3-L4 & $9.385 \pm 0.793$ & 8.448 & $9.330 \pm 0.995$ & 10.66 & $9.362 \pm 0.879$ & 9.387 \\
\hline & L4-L5 & $9.604 \pm 0.910$ & 9.479 & $9.791 \pm 0.959$ & 9.797 & $9.683 \pm 0.93$ & 9.611 \\
\hline \multirow{4}{*}{$\begin{array}{l}\text { The sum of } \\
\text { transverse and } \\
\text { sagittal dimensions }\end{array}$} & L1-L2 & $89.69 \pm 4.54$ & 5.066 & $86.92 \pm 5.20$ & 5.978 & $88.52 \pm 4.99$ & 5.642 \\
\hline & L2-L3 & $93.18 \pm 4.02$ & 4.317 & $90.91 \pm 5.35$ & 5.880 & $92.22 \pm 4.74$ & 5.136 \\
\hline & L3-L4 & $95.07 \pm 3.90$ & 4.107 & $93.52 \pm 5.62$ & 6.009 & $94.42 \pm 4.74$ & 5.019 \\
\hline & L4-L5 & $98.27 \pm 4.24$ & 4.318 & $96.53 \pm 6.35$ & 6.582 & $97.53 \pm 5.28$ & 5.410 \\
\hline \multirow{4}{*}{$\begin{array}{l}\text { The sum of three } \\
\text { sizes }\end{array}$} & L1-L2 & $98.08 \pm 4.59$ & 4.683 & $94.52 \pm 5.84$ & 6.177 & $96.57 \pm 5.42$ & 5.613 \\
\hline & L2-L3 & $102.2 \pm 4.13$ & 4.037 & $99.57 \pm 5.93$ & 5.958 & $101.1 \pm 5.11$ & 5.055 \\
\hline & L3-L4 & $104.5 \pm 4.05$ & 3.879 & $102.9 \pm 6.30$ & 6.123 & $103.8 \pm 5.15$ & 4.963 \\
\hline & L4-L5 & $107.9 \pm 4.49$ & 4.158 & $106.3 \pm 6.80$ & 6.396 & $107.2 \pm 5.60$ & 5.222 \\
\hline \multirow{4}{*}{ Cross-sectional area } & L1-L2 & $15.46 \pm 1.59$ & 10.26 & $14.55 \pm 1.76$ & 12.07 & $15.08 \pm 1.71$ & 11.35 \\
\hline & L2-L3 & $16.67 \pm 1.44$ & 8.653 & $15.88 \pm 1.92$ & 12.10 & $16.34 \pm 1.70$ & 10.39 \\
\hline & L3-L4 & $17.29 \pm 1.41$ & 8.176 & $16.72 \pm 2.10$ & 12.58 & $17.05 \pm 1.75$ & 10.27 \\
\hline & L4-L5 & $18.51 \pm 1.60$ & 8.616 & $17.89 \pm 2.43$ & 13.61 & $18.25 \pm 2.00$ & 10.98 \\
\hline
\end{tabular}




\section{Continuation of table 1.}

\begin{tabular}{|c|c|c|c|c|c|c|c|}
\hline \multirow{2}{*}{$\begin{array}{l}\text { Intervertebral discs } \\
\text { sizes }\end{array}$} & \multirow{2}{*}{ IVD } & \multicolumn{2}{|c|}{ Young men (17-21 years) } & \multicolumn{2}{|c|}{ Men (22-28 years) } & \multicolumn{2}{|c|}{ Combined group (17-28 years) } \\
\hline & & $\mathrm{M} \pm \mathrm{SD}(\mathrm{mm})$ & Cv\% & $\mathrm{M} \pm \mathrm{SD}(\mathrm{mm})$ & Cv\% & $\mathrm{M} \pm \mathrm{SD}(\mathrm{mm})$ & Cv\% \\
\hline \multirow{4}{*}{ Volume } & L1-L2 & $8.644 \pm 1.123$ & 12.99 & $7.436 \pm 1.625$ & 21.85 & $8.130 \pm 1.476$ & 18.15 \\
\hline & L2-L3 & $10.04 \pm 1.21$ & 12.03 & $9.234 \pm 1.878$ & 20.34 & $9.700 \pm 1.570$ & 16.18 \\
\hline & L3-L4 & $10.82 \pm 1.33$ & 12.28 & $10.48 \pm 2.19$ & 20.93 & $10.68 \pm 1.74$ & 16.33 \\
\hline & L4-L5 & $11.87 \pm 1.63$ & 13.74 & $11.73 \pm 2.30$ & 19.56 & $11.81 \pm 1.93$ & 16.33 \\
\hline \multirow{4}{*}{$\begin{array}{l}\text { The ratio of the sum } \\
\text { of sagittal and } \\
\text { transverse size to } \\
\text { height }\end{array}$} & L1-L2 & $10.77 \pm 1.08$ & 10.01 & $11.55 \pm 1.11$ & 9.608 & $11.10 \pm 1.15$ & 10.38 \\
\hline & L2-L3 & $10.38 \pm 0.92$ & 8.873 & $10.58 \pm 0.94$ & 8.861 & $10.46 \pm 0.93$ & 8.869 \\
\hline & L3-L4 & $10.20 \pm 0.94$ & 9.168 & $10.10 \pm 0.90$ & 8.859 & $10.16 \pm 0.92$ & 9.003 \\
\hline & L4-L5 & $10.32 \pm 1.03$ & 10.02 & $9.920 \pm 0.920$ & 9.268 & $10.15 \pm 1.00$ & 9.863 \\
\hline \multirow{4}{*}{$\begin{array}{l}\text { The ratio of the sum } \\
\text { of all sizes to the } \\
\text { height }\end{array}$} & L1-L2 & $11.77 \pm 1.08$ & 9.160 & $12.55 \pm 1.11$ & 8.842 & $12.10 \pm 1.15$ & 9.520 \\
\hline & L2-L3 & $11.38 \pm 0.92$ & 8.093 & $11.58 \pm 0.94$ & 8.096 & $11.46 \pm 0.93$ & 8.096 \\
\hline & L3-L4 & $11.20 \pm 0.94$ & 8.350 & $11.10 \pm 0.90$ & 8.061 & $11.16 \pm 0.92$ & 8.196 \\
\hline & L4-L5 & $11.32 \pm 1.03$ & 9.134 & $10.92 \pm 0.92$ & 8.420 & $11.15 \pm 1.00$ & 8.978 \\
\hline \multirow{4}{*}{$\begin{array}{l}\text { The ratio of cross- } \\
\text { sectional area to } \\
\text { height }\end{array}$} & L1-L2 & $1.857 \pm 0.248$ & 13.350 & $1.925 \pm 0.203$ & 10.55 & $1.885 \pm 0.231$ & 12.26 \\
\hline & L2-L3 & $1.857 \pm 0.215$ & 11.600 & $1.841 \pm 0.188$ & 10.20 & $1.850 \pm 0.203$ & 10.99 \\
\hline & L3-L4 & $1.854 \pm 0.210$ & 11.320 & $1.798 \pm 0.186$ & 10.35 & $1.831 \pm 0.201$ & 10.98 \\
\hline & L4-L5 & $1.942 \pm 0.234$ & 12.040 & $1.835 \pm 0.253$ & 13.78 & $1.897 \pm 0.246$ & 13,00 \\
\hline \multicolumn{2}{|l|}{ Weight, kg } & $72,15 \pm 8,06$ & 11.17 & $76.03 \pm 2.05$ & 15.41 & $73.79 \pm 9.90$ & 13.41 \\
\hline \multicolumn{2}{|l|}{ Body length, m } & $1,787 \pm 0,064$ & 3.572 & $1.775 \pm 0.077$ & 4.329 & $1.782 \pm 0.069$ & 3.897 \\
\hline \multicolumn{2}{|c|}{ Mass-growth factor, $\mathrm{g} / \mathrm{cm}$} & $403,4 \pm 38,6$ & 9.568 & $427.4 \pm 57.5$ & 13.45 & $413.5 \pm 48.7$ & 11.77 \\
\hline \multicolumn{2}{|c|}{ Mass-growth index, $\mathrm{kg} / \mathrm{m}^{2}$} & $22,58 \pm 2,05$ & 9.068 & $24.07 \pm 3.05$ & 12.67 & $23.21 \pm 2.61$ & 11.25 \\
\hline
\end{tabular}

indicators of transverse dimensions of all groups is in the range of 2 sigma from $63.46 \%$ to $76.32 \%$ of the total number of observations; the paired t-test determined (see Table 2) that there were no significant differences in the mean values of the indicators in the groups $(p>0.05)$. The difference between the mean values in the samples for IVD $D_{1-12}$ is $0.751 \mathrm{~mm}$ and $1.028 \mathrm{~mm}$, for $\mathrm{IVD}_{\mathrm{L} 2-\mathrm{L} 3}-0.501 \mathrm{~mm}$ and 0.685 $\mathrm{mm}$, for $\mathrm{IVD}_{\mathrm{L} 3 \mathrm{LL} 4}-0.257 \mathrm{~mm}$ and $0.351 \mathrm{~mm}$, for $\mathrm{IVD}_{\mathrm{L} 4-\mathrm{L} 5}$ $0.367 \mathrm{~mm}$ and $0.502 \mathrm{~mm}$.

For sagittal sizes of intervertebral discs IVD ${ }_{\mathrm{L} 1-\mathrm{L} 2}, \mathrm{IVD}_{\mathrm{L2}-\mathrm{L} 3}$, $I V D_{L 3-L 4}, I V D_{L 4-L 5}$ the distribution asymmetry indices do not differ significantly in young men and in the combined group, according to the observation groups, the asymmetry indices are $0,035,0,581$ and 0,193 ; the smallest are for $D_{L 2-L 3}$ 0.021 in young men and the largest in men for $D_{L 4-L 5}-0.782$. Coefficients of variation (see Table 1) have average values less than $10 \%$ from $4.94 \%$ to $8.15 \%$, which corresponds to the weak variability of the trait. The highest frequency for sagittal sizes of all groups is in the range of 2 sigma from $65.38 \%$ to $78.85 \%$ of the total number of observations. Thus, it can be argued that the distribution of traits in the studied groups is as close as possible to normal. When using the paired t-test, it was determined (see Table 2) that no significant differences in the mean values of the indicators in the groups were determined ( $p>0.05)$. Levene's test confirms the homogeneity of the variance of the indicators $(p>0.05)$ in the studied groups. The difference between the mean values of sagittal dimensions in the samples for IVD ${ }_{\mathrm{L} 1-\mathrm{L} 2}$ is $0.419 \mathrm{~mm}$ and $0.573 \mathrm{~mm}$, for $\mathrm{IVD}_{\mathrm{L} 2 \mathrm{~L} \mathrm{L3}}-0.461 \mathrm{~mm}$ and $0.630 \mathrm{~mm}$, for $\mathrm{IVD}_{\mathrm{L3}-\mathrm{L} 4}-0.396 \mathrm{~mm}$ and $0.542 \mathrm{~mm}$, for IVD $\mathrm{L}_{\mathrm{L}-\mathrm{L} 5}-0.368 \mathrm{~mm}$ and $0.504 \mathrm{~mm}$.

The coefficients of variation of the average height (see Table 1) of all groups have values close to low variability ( $\leq 10$ ) - from $8.21 \%$ to $11.75 \%$. The paired t-test (see Table 2) revealed significant differences in the mean values of the average height for IVD $D_{L 1-L 2}, I V D_{L 2-L 3}, I V D_{L 3-L 4}, I V D_{L 4-L 5}$ ( $p>0.05)$ significant differences in mean values are absent. Levene's test confirmed the homogeneity of the variance of the indicators $(p>0.05)$ in all study groups for all intervertebral discs. The bilateral $d$-criterion of the Kolmogorov-Smirnov type did not exceed the critical value (0.05). The difference between the mean values in the samples for IVD $D_{L 1-L 2}$ is $0.334 \mathrm{~mm}$ and $0.458 \mathrm{~mm}$, for $\mathrm{IVD}_{\mathrm{L} 2 \mathrm{~L} \mathrm{~L} 3}-0.158 \mathrm{~mm}$ and $0.216 \mathrm{~mm}$, for $\mathrm{IVD}_{\mathrm{L3-L4}}-0.023 \mathrm{~mm}$ and $0.032 \mathrm{~mm}$, for IVD $\mathrm{LA-L5}_{-}-0.079 \mathrm{~mm}$ and $0.108 \mathrm{~mm}$.

The following parameters were calculated: the sum of sagittal and transverse dimensions, the sum of three dimensions, the cross-sectional area and the volume of the intervertebral discs.

The coefficients of variation of the sum of transverse and sagittal sizes (see Table 1) have average values corresponding to the weak variability of the trait - from $4.11 \%$ 
to $6.58 \%$. The highest frequencies for the sum of transverse and sagittal sizes of all groups are in the range of 2 sigma from $65.38 \%$ to $76.32 \%$ of the total number of observations.
Indicators of the paired t-test (see Table 2) for the sums of transverse and sagittal sizes IVD ${ }_{\mathrm{L} 1-\mathrm{L} 2}, I_{\mathrm{L}} \mathrm{D}_{\mathrm{L} 2-\mathrm{L3}}, \mathrm{IVD}_{\mathrm{L} 3-\mathrm{L} 4}$, $I V D_{L 4-L 5}$ of the lumbar spine in adolescents, men of the first

Table 2. Indicators of $t$-test of intervertebral disks sizes $I V D_{L 1-L 2}, I V D_{L 2-L 3}, I V D_{L 3-L 4}, I V D_{L 4-L 5}$ of lumbar spine in adolescents, in men of the first period of adulthood and in the combined group.

\begin{tabular}{|c|c|c|c|}
\hline $\begin{array}{l}\text { Intervertebral discs } \\
\text { sizes }\end{array}$ & Comparison groups & t-value & $p$ \\
\hline \multirow{8}{*}{ Anterior height } & D1 $17-21$ vs. D1 17-28 & 1.330 & 0.186 \\
\hline & D1 $22-28$ vs. D1 $17-28$ & -1.468 & 0.145 \\
\hline & D2 $17-21$ vs. D2 $17-28$ & 0.042 & 0.966 \\
\hline & D2 $22-28$ vs. D2 $17-28$ & -0.051 & 0.960 \\
\hline & D3 $17-21$ vs. D3 $17-28$ & -0.602 & 0.548 \\
\hline & D3 $22-28$ vs. D3 $17-28$ & 0.657 & 0.513 \\
\hline & D4 17-21 vs. D4 17-28 & -0.982 & 0.328 \\
\hline & D4 22-28 vs. D4 $17-28$ & 1.176 & 0.242 \\
\hline \multirow{8}{*}{ Posterior height } & D1 $17-21$ vs. D1 17-28 & 2.453 & 0.015 \\
\hline & D1 22-28 vs. D1 17-28 & -3.006 & 0.003 \\
\hline & D2 $17-21$ vs. D2 $17-28$ & 1.429 & 0.155 \\
\hline & D2 $22-28$ vs. D2 $17-28$ & -1.694 & 0.093 \\
\hline & D3 $17-21$ vs. D3 $17-28$ & 0.719 & 0.473 \\
\hline & D3 $22-28$ vs. D3 $17-28$ & -0.894 & 0.373 \\
\hline & D4 $17-21$ vs. D4 $17-28$ & -0.023 & 0.982 \\
\hline & D4 22-28 vs. D4 17-28 & 0.028 & 0.978 \\
\hline \multirow{8}{*}{ Transverse size } & D1 $17-21$ vs. D1 17-28 & 1.448 & 0.150 \\
\hline & D1 $22-28$ vs. D1 $17-28$ & -1.695 & 0.092 \\
\hline & D2 $17-21$ vs. D2 17-28 & 0.992 & 0.323 \\
\hline & D2 $22-28$ vs. D2 $17-28$ & -1.139 & 0.257 \\
\hline & D3 $17-21$ vs. D3 $17-28$ & 0.521 & 0.603 \\
\hline & D3 $22-28$ vs. D3 $17-28$ & -0.584 & 0.560 \\
\hline & D4 $17-21$ vs. D4 17-28 & 0.693 & 0.489 \\
\hline & D4 22-28 vs. D4 17-28 & -0.794 & 0.429 \\
\hline \multirow{8}{*}{ Sagittal size } & D1 $17-21$ vs. D1 17-28 & 0.955 & 0.341 \\
\hline & D1 22-28 vs. D1 17-28 & -1.150 & 0.252 \\
\hline & D2 $17-21$ vs. D2 $17-28$ & 1.141 & 0.256 \\
\hline & D2 $22-28$ vs. D2 $17-28$ & -1.332 & 0.185 \\
\hline & D3 $17-21$ vs. D3 $17-28$ & 0.964 & 0.337 \\
\hline & D3 $22-28$ vs. D3 $17-28$ & -1.046 & 0.298 \\
\hline & D4 $17-21$ vs. D4 $17-28$ & 0.861 & 0.391 \\
\hline & D4 $22-28$ vs. D4 $17-28$ & -0.909 & 0.365 \\
\hline \multirow{8}{*}{$\begin{array}{c}\text { The average value of } \\
\text { the height }\end{array}$} & D1 $17-21$ vs. D1 $17-28$ & 2.282 & 0.024 \\
\hline & D1 $22-28$ vs. D1 $17-28$ & -2.646 & 0.009 \\
\hline & D2 $17-21$ vs. D2 $17-28$ & 1.129 & 0.261 \\
\hline & D2 $22-28$ vs. D2 $17-28$ & -1.297 & 0.197 \\
\hline & D3 $17-21$ vs. D3 $17-28$ & 0.156 & 0.876 \\
\hline & D3 $22-28$ vs. D3 17-28 & -0.179 & 0.859 \\
\hline & D4 $17-21$ vs. D4 $17-28$ & -0.491 & 0.624 \\
\hline & D4 $22-28$ vs. D4 $17-28$ & 0.594 & 0.553 \\
\hline
\end{tabular}

\begin{tabular}{|c|c|c|c|}
\hline $\begin{array}{c}\text { Intervertebral discs } \\
\text { sizes }\end{array}$ & Comparison groups & $\mathrm{t}$-value & $\mathrm{p}$ \\
\hline \multirow{8}{*}{$\begin{array}{l}\text { The sum of transverse } \\
\text { and sagittal } \\
\text { dimensions }\end{array}$} & D1 $17-21$ vs. D1 $17-28$ & 1.389 & 0.167 \\
\hline & D1 22-28 vs. D1 17-28 & -1.637 & 0.104 \\
\hline & D2 $17-21$ vs. D2 17-28 & 1.230 & 0.221 \\
\hline & D2 $22-28$ vs. D2 $17-28$ & -1.382 & 0.170 \\
\hline & D3 $17-21$ vs. D3 $17-28$ & 0.841 & 0.402 \\
\hline & D3 $22-28$ vs. D3 17-28 & -0.921 & 0.359 \\
\hline & D4 $17-21$ vs. D4 17-28 & 0.857 & 0.393 \\
\hline & D4 22-28 vs. D4 17-28 & -0.926 & 0.356 \\
\hline \multirow{8}{*}{ The sum of three sizes } & D1 $17-21$ vs. D1 $17-28$ & 1.681 & 0.095 \\
\hline & D1 $22-28$ vs. D1 17-28 & -1.918 & 0.057 \\
\hline & D2 $17-21$ vs. D2 17-28 & 1.346 & 0.181 \\
\hline & D2 $22-28$ vs. D2 $17-28$ & -1.476 & 0.142 \\
\hline & D3 $17-21$ vs. D3 $17-28$ & 0.812 & 0.418 \\
\hline & D3 $22-28$ vs. D3 17-28 & -0.867 & 0.388 \\
\hline & D4 $17-21$ vs. D4 $17-28$ & 0.722 & 0.472 \\
\hline & D4 $22-28$ vs. D4 $17-28$ & -0.777 & 0.439 \\
\hline \multirow{8}{*}{ Cross-sectional area } & D1 $17-21$ vs. D1 $17-28$ & 1.323 & 0.188 \\
\hline & D1 $22-28$ vs. D1 17-28 & -1.575 & 0.118 \\
\hline & D2 $17-21$ vs. D2 17-28 & 1.193 & 0.235 \\
\hline & D2 $22-28$ vs. D2 $17-28$ & -1.340 & 0.183 \\
\hline & D3 $17-21$ vs. D3 $17-28$ & 0.843 & 0.400 \\
\hline & D3 $22-28$ vs. D3 $17-28$ & -0.913 & 0.363 \\
\hline & D4 $17-21$ vs. D4 17-28 & 0.810 & 0.419 \\
\hline & D4 $22-28$ vs. D4 $17-28$ & -0.871 & 0.386 \\
\hline \multirow{8}{*}{$\begin{array}{l}\text { The volume of the } \\
\text { intervertebral disc }\end{array}$} & D1 $17-21$ vs. D1 17-28 & 2.155 & 0.033 \\
\hline & D1 $22-28$ vs. D1 17-28 & -2.370 & 0.019 \\
\hline & D2 17-21 vs. D2 17-28 & 1.355 & 0.178 \\
\hline & D2 $22-28$ vs. D2 $17-28$ & -1.451 & 0.149 \\
\hline & D3 $17-21$ vs. D3 $17-28$ & 0.512 & 0.609 \\
\hline & D3 $22-28$ vs. D3 $17-28$ & -0.537 & 0.592 \\
\hline & D4 $17-21$ vs. D4 17-28 & 0.178 & 0.859 \\
\hline & D4 22-28 vs. D4 17-28 & -0.196 & 0.845 \\
\hline \multirow{8}{*}{$\begin{array}{c}\text { The ratio of the sum of } \\
\text { sagittal and transverse } \\
\text { size to height }\end{array}$} & D1 $17-21$ vs. D1 $17-28$ & -1.671 & 0.097 \\
\hline & D1 $22-28$ vs. D1 17-28 & 2.034 & 0.054 \\
\hline & D2 $17-21$ vs. D2 $17-28$ & -0.526 & 0.600 \\
\hline & D2 22-28 vs. D2 17-28 & 0.644 & 0.521 \\
\hline & D3 $17-21$ vs. D3 $17-28$ & 0.257 & 0.798 \\
\hline & D3 $22-28$ vs. D3 $17-28$ & -0.321 & 0.749 \\
\hline & D4 17-21 vs. D4 17-28 & 0.943 & 0.347 \\
\hline & D4 22-28 vs. D4 17-28 & -1.204 & 0.231 \\
\hline
\end{tabular}




\section{Continuation of table 2.}

\begin{tabular}{|c|c|c|c|}
\hline $\begin{array}{l}\text { Intervertebral discs } \\
\text { sizes }\end{array}$ & Comparison groups & t-value & $p$ \\
\hline \multirow{8}{*}{$\begin{array}{l}\text { The ratio of the sum of } \\
\text { all sizes to the height }\end{array}$} & D1 $17-21$ vs. D1 $17-28$ & -1.671 & 0.097 \\
\hline & D1 $22-28$ vs. D1 17-28 & 2.034 & 0.044 \\
\hline & D2 $17-21$ vs. D2 17-28 & -0.526 & 0.600 \\
\hline & D2 $22-28$ vs. D2 17-28 & 0.644 & 0.521 \\
\hline & D3 $17-21$ vs. D3 $17-28$ & 0.257 & 0.798 \\
\hline & D3 $22-28$ vs. D3 $17-28$ & -0.321 & 0.749 \\
\hline & D4 17-21 vs. D4 17-28 & 0.943 & 0.347 \\
\hline & D4 $22-28$ vs. D4 17-28 & -1.204 & 0.231 \\
\hline \multirow{15}{*}{$\begin{array}{l}\text { The ratio of cross- } \\
\text { sectional area to } \\
\text { height }\end{array}$} & D1 $17-21$ vs. D1 17-28 & -0.692 & 0.490 \\
\hline & D1 22-28 vs. D1 17-28 & 0.906 & 0.366 \\
\hline & D2 $17-21$ vs. D2 17-28 & 0.183 & 0.855 \\
\hline & D2 $22-28$ vs. D2 $17-28$ & -0.236 & 0.814 \\
\hline & D3 $17-21$ vs. D3 $17-28$ & 0.665 & 0.507 \\
\hline & D3 $22-28$ vs. D3 $17-28$ & -0.850 & 0.397 \\
\hline & D4 17-21 vs. D4 17-28 & 1.077 & 0.283 \\
\hline & D4 22-28 vs. D4 17-28 & -1.293 & 0.198 \\
\hline & D1 22-28 vs. D1 17-28 & -1.575 & 0.118 \\
\hline & D2 $17-21$ vs. D2 17-28 & 1.193 & 0.235 \\
\hline & D2 $22-28$ vs. D2 $17-28$ & -1.340 & 0.183 \\
\hline & D3 $17-21$ vs. D3 $17-28$ & 0.843 & 0.400 \\
\hline & D3 $22-28$ vs. D3 $17-28$ & -0.913 & 0.363 \\
\hline & D4 17-21 vs. D4 17-28 & 0.810 & 0.419 \\
\hline & D4 $22-28$ vs. D4 17-28 & -0.871 & 0.386 \\
\hline \multirow{2}{*}{ Body weight (kg) } & D1 $17-21$ vs. D1 $17-28$ & -1.012 & 0.313 \\
\hline & D1 22-28 vs. D1 17-28 & 1.105 & 0.271 \\
\hline \multirow{2}{*}{ Body length, m } & D2 $17-21$ vs. D2 17-28 & 0.412 & 0.681 \\
\hline & D2 $22-28$ vs. D2 17-28 & -0.478 & 0.634 \\
\hline \multirow{2}{*}{$\begin{array}{l}\text { Mass-growth factor, } \\
\mathrm{g} / \mathrm{cm}\end{array}$} & D3 17-21 vs. D3 17-28 & -1.286 & 0.201 \\
\hline & D3 $22-28$ vs. D3 $17-28$ & 1.394 & 0.166 \\
\hline \multirow{2}{*}{$\begin{array}{l}\text { Mass-growth index, } \\
\mathrm{kg} / \mathrm{m}^{2}\end{array}$} & D4 17-21 vs. D4 17-28 & -1.492 & 0.138 \\
\hline & D4 22-28 vs. D4 17-28 & 1.620 & 0.108 \\
\hline
\end{tabular}

period of adulthood and in the combined the group proved the absence of significant differences in mean values $(p>0.05)$.

The coefficients of variation for the sum of the three sizes (see Table 2) have average values from $3.88 \%$ to $6.40 \%$, which corresponds to the weak variability of the trait. The indicators of distribution asymmetry are small, on average do not differ significantly (according to the observation groups $-0.199,0.498$ and 0.054$)$, the lowest for $D_{L 4-L 5}-0.004$ in young men and the highest for IVD $D_{L 2-L 3}$ in men - 0.832. T-test and Levene's test scores for the sum of all sizes $I V D_{L 1-L 2}, I V D_{L 2-L 3}, I V D_{L 3-L 4}, I V D_{L 4-L 5}$ did not show significant differences in mean values in the groups $(p>0.05)$.

The coefficients of variation of cross-sectional areas for intervertebral discs IVD $D_{L 1-L 2}, I V D_{L 2-L 3}, I V D_{L 3-L 4}, I V D_{L 4-L 5}$ had average values close to low variability $(\leq 10)$ - from $8.18 \%$ to $13.61 \%$. When using the paired t-test, it was determined that no significant differences in the mean values of the indicators in the groups were determined ( $p>0.05$ ).

Coefficients of variation of intervertebral disc volumes have average values within the average variability - from $12.03 \%$ to $21.85 \%$. When using the paired t-test, it was

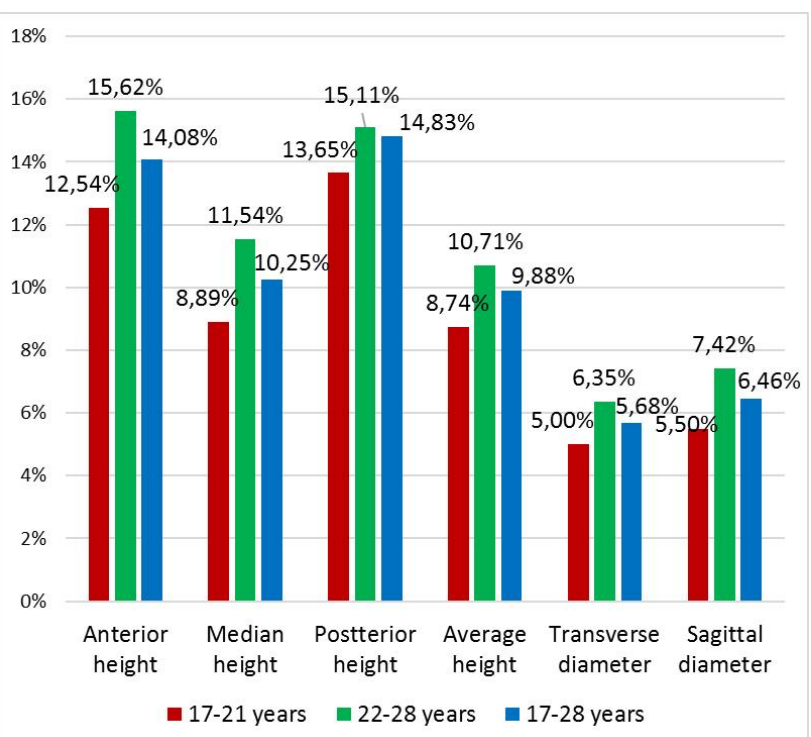

Fig. 1. Coefficients of variation of anterior, middle, average heights, transverse and sagittal sizes of intervertebral discs IVD ${ }_{\mathrm{L} 1-\mathrm{L} 2}, \mathrm{IVD}_{\mathrm{L} 2}$ ${ }_{L 3}, I V D_{L 3-L 4}, I V D_{L 4-L 5}$ in young men (17-21 years), in men of the first period of adulthood (22-28 years) and in the combined group (1728 years).

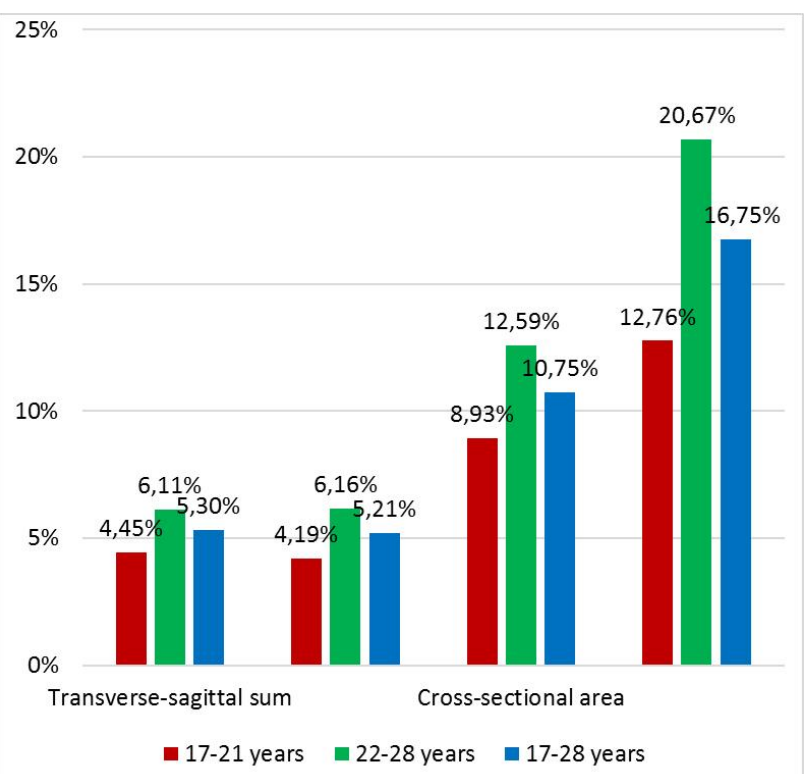

Fig. 2. Coefficients of variation of indicators of the sum of crosssectional and sagittal sizes, the sum of all sizes, cross-sectional areas and volumes of intervertebral disks IVD ${ }_{L 1-L 2}, I V D_{L 2-L 3}, I V D_{L 3}$ ${ }_{L 4}, I V D_{L 4-L 5}$ in young men (17-21 years), in men of the first period of adulthood (22-28 years) and in the combined group (17-28 years). 


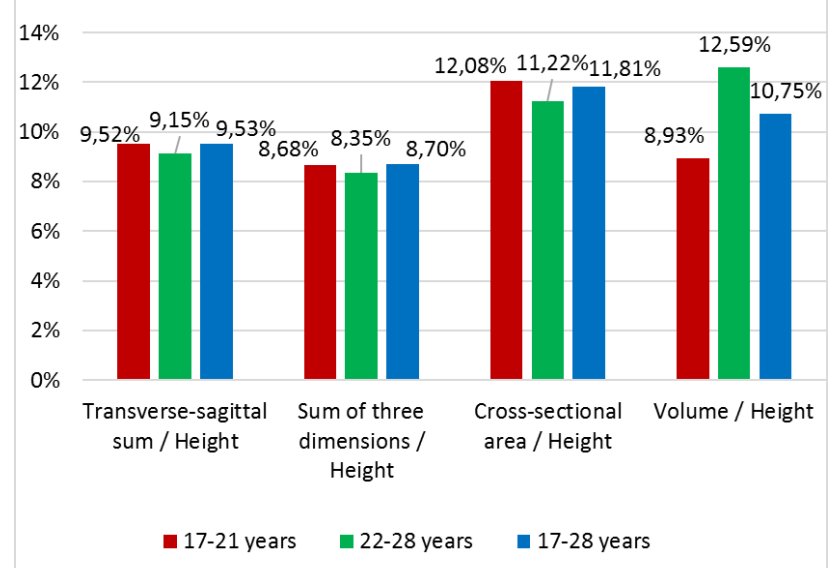

Fig. 3. Coefficients of variation of relative indicators of the sum of transverse and sagittal sizes, the sum of all sizes, cross-sectional areas and volumes of intervertebral disks IVD $\mathrm{L} 1 \mathrm{~L}$ 2 $_{1}, \mathrm{IVD}_{\mathrm{L} 2 \mathrm{~L}-\mathrm{L} 3}, \mathrm{IVD}_{\mathrm{L} 3-}$ ${ }_{L 4}, I V D_{L 4-L 5}$ to the average height in young men (17-21 years), in men of the first period of adulthood (22-28 years) and in the combined group (17-28 years).

determined that significant differences in the mean values of the indicators in the groups were not determined for $I V D_{\text {L1-L2 }}, I V D_{\text {L2-L3}}, I V D_{\text {L3-L4 }}, I V D_{\text {L4- L5 }}(p>0.05)$.

The increase in the coefficients of variation of the areas of transverse dimensions and their volumes attracts attention (Fig. 2). The average values of the coefficients of variation for the sums of transverse and sagittal sizes $5.29 \%$, for the sum of the three sizes of intervertebral discs and $5.19 \%$, for cross-sectional areas $-10.75 \%$, for the volumes of intervertebral discs - $16.73 \%$. Thus, the coefficients of variation of the cross-sectional areas of the intervertebral discs are on average more than 2 times (2.033 and 2.073) and the volumes more than 3 times (3.162 and 3.223) higher than the coefficients of variation of the sums of the transverse and sagittal sizes and the sum of three sizes.

Coefficients of variation of the ratio of the sum of sagittal and transverse size to height (see Table 1) of all groups have average values close to low variability $(\leq 10)$ - from $8.86 \%$ to $10.38 \%$, for the ratio of cross-sectional areas to height disks coefficients of variation from $10.20 \%$ to $13.78 \%$, for the ratio of disk volumes to height - from $8.18 \%$ to $13.61 \%$.

T-test indicators (see Table 2) for the ratios of the sums of sagittal and transverse dimensions, the ratios of crosssectional areas, the ratios of disk volumes to the height $I V D_{L 1-L 2}, I V D_{L 2-L 3}, I V D_{L 2-L 4}, I V D_{L 4-L 5}$ of the lumbar spine in young men, men of the first period of adulthood and in the combined group show no significant differences in the average values of these indicators in the groups $(p>0.05)$.

The coefficients of variation of the ratio of the sum of the three dimensions to the height (see Table 1) are characterized by low variability, their values range from $8.06 \%$ to $9.52 \%$. The highest frequency for the ratio of the sum of all sizes to the height of the studied groups are in the range of 2 sigma from $65.38 \%$ to $86.84 \%$ of the total number of observations. When using the paired t-test (see Table 2), significant differences in the mean values of the indicators in the groups were not determined ( $p>0.05$ ).

Body weight had significant moderate correlations with transverse dimensions of intervertebral discs (IVDs) $(r=0.45)$, with the sum of transverse and sagittal dimensions of IVDs $(r=0.43)$, with the sum of three sizes of IVDs $(r=0.43)$, with a cross-sectional area of IVDs $(r=0.41)$, with a volume of IVDs $(r=0.37)$.

Body length was characterized by the presence of significant moderate correlations with sagittal sizes of IVDs $(r=0.48)$, with the volume of IVDs $(r=0.49)$; noticeable correlations were observed with the transverse dimensions of IVDs $(r=0.51)$, with the sum of the transverse and sagittal dimensions of IVDs $(r=0.56)$, with the sum of the three dimensions of IVDs $(r=0.56)$, with the cross-sectional area of IVDs $(r=0.56)$.

The mass-growth factor had a weak correlation with the transverse dimensions of IVDs ( $r=0.35)$, with the sum of the transverse and sagittal dimensions of IVDs $(r=0.30)$, with the sum of the three dimensions of IVDs $(r=0.31)$.

The mass-growth index had no significant correlations with anterior, posterior, and average height and sagittal size of IVDs $(r<0.10)$ and had only significant weak correlations with mean height $(r=0.12)$ and transverse dimensions of IVDs $(r=0.19)$.

\section{Discussion}

The variability of quantitative traits is a biological feature of the organism and is due to the genotype and environmental conditions. The problem of variability of symptoms has been relevant for centuries and not only in medicine. As early as the mid-nineteenth century, one of the founders of experimental medicine, the French scientist Claude Bernard, argued that if we could prove that deviation from the norm is a simple quantitative deviation, then we would have the key to treating any particular person, regardless, how its individual indicators differ from those of other people [3]. Nowadays, an important area of improvement in medicine is to identify the parameters of individual variability of the norm, which is the basis for early preclinical detection of abnormalities. The use of averages as indicators of the norm does not take into account individuality and can be a factor in misinterpretations of the results.

Determination of the linear dimensions of the vertebral bodies and intervertebral discs has diagnostic value [2, 7 , $11,14,18]$, which is due to the relevance of this topic, due to the high prevalence of spinal pathology $[6,28]$.

Our results show no significant differences in the studied groups in terms of anterior and middle height in the groups of young men, men and in the combined group. Regarding the posterior height of the intervertebral discs when using the paired t-test, there was a significant 
difference between the mean values in the groups for IVDL1L2 6,159 $\pm 0,921 \mathrm{~mm}, 7,182 \pm 0,932 \mathrm{~mm}$ for young men and men, the difference between the mean values was 1,023 $\mathrm{mm}$. This indicator has significant variability due to the variability (individuality) of lumbar lordosis, which largely depends on conscious posture control [31] and has a fairly wide range of norm $\left(20^{\circ}-45^{\circ}\right)$ [19].

The coefficient of variation serves as a characteristic of variability (scattering) and is a criterion for the homogeneity of the population. Comparison of the average coefficients of variation (see Fig. 1) of medium and average heights with the indicators of the anterior and posterior vertical dimensions shows much less variability of the former. The values of the coefficients of variation of the anterior and posterior heights from $12.54 \%$ to $15.62 \%$ refer to the average variability, and the coefficients of variation for the middle height $(8.74 \%, 10.71 \%, 9.88 \%)$ and for the average height $(8,89 \%, 11.54 \%, 10.25 \%)$ are as close as possible to low variability. The variability for the average heights in the studied groups is insignificant, but less than for the middle heights. Thus, the use of variable front and rear heights in the integrated indicator (average height) not only does not increase the variability of the latter, but also slightly reduces it, proving their interdependence. These results indicate the advantages of using the average height of the intervertebral disc for further mathematical analysis.

Degenerative changes of intervertebral discs are accompanied by changes in the MR signal from the nucleus pulposus and fibrous ring (Pfirrmann degeneration scores) due to dehydration of varying degrees, structural changes in fibrous, cartilaginous elements, and changes in the closing plates of adjacent vertebrae [10] and protrusion of the nucleus pulposus in the form of protrusions, extrusions and sequesters.

Reduction of the height of the unaltered disc due to uniform stretching of the fibers of the fibrous ring, followed by its uniform thinning without local damage to the fibrous ring and without pathological changes in the closing plates of adjacent vertebrae also occurs. With this variant of deformation of the intervertebral disc there is a change in shape without changing its volume due to redistribution, while there is an increase in the area of the intervertebral disc with decreasing height. The described scenario of changes does not fit into the traditional model and is not taken into account by clinicians. The increase in area is usually accompanied by an increase in sagittal and transverse dimensions with a simultaneous decrease in the height of the intervertebral disc and an increase in pressure on the fibrous ring.

The high variability of indicators of cross-sectional areas and volumes of intervertebral discs determines the lower suitability of these indicators for further processing, reduces the reliability of the conclusions obtained on their basis.

Significant differences in the coefficients of variation of the sums of transverse and sagittal sizes and the sum of three sizes are not defined, which is also confirmed by the absence of a significant difference in the ratios of their average values and their standard errors [15].

The homogeneity of the sample and belonging to one general population is evidenced by the weak variability of the trait with a coefficient of variation not exceeding $10 \%$ [26]. Given the results obtained, it can be argued that the relative ratio of the sum of the three dimensions to the height has the most homogeneous sampling rates.

Total somatometric features and indices have their own characteristics in variability. The least variable is the length of the body - from $3.57 \%$ in young men to $4.33 \%$ in men without significant differences between groups of studies. Body weight variability increased in the male group to $15.41 \%$ compared to $11.17 \%$ of young men. The massgrowth coefficient and the mass-growth index, respectively, also show a tendency to higher values for these age groups, as body weight plays a dominant role in these calculated indicators.

Correlation analysis showed that the arithmetic mean values of the correlation coefficients of the linear dimensions of IVDs were the smallest for the mass-growth index and the largest for body length. The mass-growth index had the lowest correlation coefficients with the measured parameters of the intervertebral discs, with the maximum value for the transverse dimensions of the intervertebral discs $(r=0.19)$, which calls into question the further use of the indicator in the simulation.

Given the observed variability in posterior and anterior intervertebral disc heights and the relatively smaller difference between the mean values in the IVD1 average height groups in subsequent studies, more vertical vertebral disc measurements are likely to be made to determine the average height. Increasing the number of vertical measurements of the intervertebral disc will, among other things, increase the accuracy of calculating the area of the upper and lower surfaces of the intervertebral disc, its volume and reduce the influence of posture on the average height.

\section{Conclusions}

1. The gradual increase of linear indicators of the anterior, middle and posterior vertical dimensions, sagittal and transverse dimensions of the intervertebral discs from L1-L2 to L4-L5 segment is determined. There are no significant differences in the linear dimensions of the intervertebral discs (except for L1-L2) in the studied groups.

2. The sums of transverse and sagittal sizes, the sums of three sizes and the average height of the intervertebral discs, also increase proportionally in the caudal direction, have a distribution as close as possible to normal and is more acceptable for further mathematical regression analysis, as their coefficients of variation are 2 times smaller than in cross-sectional areas and 3 times smaller than in volumes.

3. The determined ratios of the sum of sagittal and transverse size and the sum of three sizes to the average 
height of intervertebral discs are homogeneous, have low variability (coefficients of variation from $8.09 \%$ to $9.52 \%$ ), correspond to the characteristics of the general population and can serve as auxiliary quantitative indicators assessment of the norm for intervertebral discs.

4. Body weight and length have relatively higher correlation coefficients with the sums of sagittal and transverse dimensions, the sums of three dimensions and

\section{References}

[1] Adams, M.A. (2004). Biomechanics of back pain. Acupunct. Med., 22(4), 178-188. doi: 10.1136/aim.22.4.178

[2] Alam, M.M., Waqas, M., Shallwani, H., \& Javed, G. (2014). Lumbar morphometry: a study of lumbar vertebrae from a pakistani population using computed tomography scans. Asian Spine Journal, 8(4), 421-426. https://doi.org/10.4184/ asj.2014.8.4.421

[3] Bernard, К. (2010). Введение к изучению опытной медицины [An introduction to the study of experienced medicine]. М.: Красанд - М.: Krasand.

[4] Bezsmertnyi, Yu.O., \& Bezsmertna, H.V. (2018). Аналіз рекомендацій з медичної реабілітації осібз інвалідністю [Analysis of recommendations for medical rehabilitation of persons with disabilities]. Медицина болю - Pain Medicine, 3(2/1), 11-12. doi.org/10.31636/pmjua.t1.34530

[5] Bozhenko, N.L. (2015). Біль у спині: деякі аспекти діагностики та лікування [Back pain: some aspects of diagnosis and treatment]. Ліки України - Medicines of Ukraine, 190(4), 5865.

[6] Cai, X.Y., Sun, M.S., Huang, Y.P., Liu, Z.X., Liu, C.J., Du, C.F., \& Yang, Q. (2020). Biomechanical Effect of L4-L5 Intervertebral Disc Degeneration on the Lower Lumbar Spine: A Finite Element Study. Orthopaedic Surgery, 12(3), 917-930. https://doi.org/ 10.1111/os. 12703

[7] Campbell-Kyureghyan, N., Jorgensen, M., Burr, D., \& Marras, W. (2005). The prediction of lumbar spine geometry: method development and validation. Clinical Biomechanics (Bristol, Avon), 20(5), 455-464. https://doi.org/10.1016/ j.clinbiomech.2005.01.006

[8] Feng, H., Li, H., Ba, Z., Chen, Z., Li, X., \& Wu, D. (2019). Morphometry evaluations of cervical osseous endplates based on three dimensional reconstructions. International Orthopaedics, 43(6), 1521-1528. https://doi.org/10.1007/ s00264-018-4053-1

[9] Gertzbein, S.D., Seligman, J., \& Holtby, R. (1985). Centrode patterns and segmental instability in degenerative disc disease. Spine (Phila Pa 1976), 10(3), 257-261 . doi: 10.1097/00007632198504000-00014

[10] Griffith, J.F., Wang, Y.X., Antonio, G.E., Choi, K.C., Yu, A., Ahuja, A.T., \& Leung, P.C. (2007). Modified Pfirrmann grading system for lumbar intervertebral disc degeneration. Spine, 32(24), E708-E712. https://doi.org/10.1097/ BRS.0b013e31815a59a0

[11] Grivas, T.B., Savvidou, O., Binos, S., Vynichakis, G., Lykouris, D., Skaliotis, M. ...Velissarios, K. (2019). Morphometric characteristics of the thorac-lumbar and lumbar vertebrae in the Greek population: a computed tomography-based study on 900 vertebrae-"Hellenic Spine Society (HSS) 2017 Award Winner". Scoliosis and Spinal Disorders, 14, 2. https://doi.org/ 10.1186/s13013-019-0176-4

[12] Hayes, A.F., \& Cai, L. (2007). Further evaluating the conditional decision rule for comparing two independent means. The cross-sectional areas than with other parameters of the intervertebral discs. With almost equal correlation coefficients, lower variability in the sum of the transverse and sagittal dimensions and the sums of the three dimensions make them more acceptable for further mathematical modeling than the calculated values of crosssectional areas and volumes.

British Journal of Mathematical and Statistical Psychology, 60(2), 217-244. https://doi.org/10.1348/000711005X62576

[13] Huang, R.C., Lim, M.R., Girardi, F.P. \& Cammisa Jr, F.P. (2004) The prevalence of contraindications to total disc replacement in a cohort of lumbar surgical patients. Spine (Phila Pa 1976) 29(22), 2538-2541. doi: 10.1097/01.brs.0000144829.57885.20

[14] Iliescu, D.M., Bordei, P., lonescu, E.V., Albina, S., Oprea, C., Obada, B. ... Iliescu, M.G. (2017). Anatomic-Imaging Correlations of Lumbar Disk-Vertebral Morphometric Indices. Int. J. Morphol., 35(4), 1553-1559. http://dx.doi.org/10.4067/ S0717-95022017000401553

[15] Kokorina, N.V., \& Tatarintsev, P.В. (2010). Методические вопросы выбора тест-объектов биоиндикации с использованием алгоритма сравнения коэффициентов вариации [Methodological issues of choosing test objects for bioindication using the algorithm for comparing the coefficients of variation]. Вестник Томского государственного универсuтета. Биология - Bulletin of Tomsk State University. Biology, 11(3), 141-151.

[16] Kornus, O.H., Kornus, A.O., Shyshchuk, V.D., \& Nurein, N.M. (2018). Regional morbidity profile of the Sumy region population by diseases of the musculoskeletal system and connective tissue. Journal of Geology, Geography and Geoecology, 27(3), 431-443. doi.org/10.15421/11188201

[17] Leckie, S., \& Kang, J. (2009). Recent advances in nucleus pulposus replacement technology. Current Orthopaedic Practice, 20(3), 222-226 doi: 10.1097/ BCO.0b013e31819d5bdd

[18] Lee, K., Shin, J.S., Lee, J., Lee, Y.J., Kim, M.R., Seong, I., ... Ha, I. (2017). Lumbar intervertebral disc space height in disc herniation and degeneration patients aged 20 to 25 . Int. J. Clin. Exp. Med., 10(4), 6828-6836.

[19] Lin, R.M., Jou, I.M., \& Yu, C.Y. (1992). Lumbar lordosis: normal adults. Journal of the Formosan Medical Association = Taiwan yi zhi, 91(3), 329-333.

[20] Linhardt, O., Grifka, J., \& Benditz, A. (2016). Are There Correlations Between Disc Degeneration and the Appearance of Lumbar Disc Herniations? Zh. Orthop. Unfall., 154(6), 595600. doi: $10.1055 / \mathrm{s}-0042-109568$

[21] Maher, C., Underwood, M., \& Buchbinder, R. (2017). Nonspecific low back pain. Lancet, 389, 736-747. doi.org/10.1016/ S0140-6736(16)30970-9

[22] Niankovskyi, S.L., \& Plastunova, O.B. (2016). Особливості стану здоров'я, рухової активності та харчування школярів-спортсменів (огляд літератури) [Features of the state of health, motor activity and nutrition of athletes (review of literature)]. Буковинський медичний вісник - Bukovynian Medical Bulletin, 20(1), 77, 206-214.

[23] Ninel, V.G., Norkin, N.A., \& Ostrovsky, V.V. (2008). Лечение хронических дискогенных болевых и радикуломиелопатических синдромов у больных с поясничным остеохондрозом [Treatment of chronic discogenic pain and 
radiculomyelopathic syndromes in patients with lumbar osteochondrosis]. Саратов: Новый ветер - Saratov: Novyy veter.

[24] Nordstokke, D.W. \& Zumbo, B.D. (2007). A Cautionary Tale about Levene's Tests for Equal Variances. Journal of Educational Research \& Policy Studies, 7(1), 1-14.

[25] Orlov, A.I. (2014). Непараметрические критерии согласия Колмогорова, Смирнова, омега-квадрат и ошибки при их применении [Nonparametric goodness-of-fit kolmogorov, smirnov, omega-square tests and the errors in their application]. Научный журнал КубГАУ - Scientific journal of the Kuban State Agrarian University, 97(03), 1-29.

[26] Popov, G.I. (2007). Высшая математика и математическая статистика [Higher mathematics and mathematical statistics]. М.: Физическая культура - М.: Physical culture.

[27] Schmidt, H., \& Reitmaier, S. (2013). Is the ovine intervertebral disc a small human one? A finite element model study. Journal of the Mechanical Behavior of Biomedical Materials, 17, 229241. https://doi.org/10.1016/j.jmbbm.2012.09.010

[28] Shmagel, A., Foley, R., \& Ibrahim, H. (2016). Epidemiology of
Chronic Low Back Pain in US Adults: Data From the 20092010 National Health and Nutrition Examination Survey. Arthritis Care \& Research, 68(11), 1688-1694. https://doi.org/10.1002/ acr.22890

[29] Tang, R., Gungor, C., Sesek, R.F., Foreman, K.B., Gallagher, S., \& Davis, G.A. (2016). Morphometry of the lower lumbar intervertebral discs and endplates: comparative analyses of new MRI data with previous findings. European Spine Journal, 25(12), 4116-4131. doi: 10.1007/s00586-016-4405-8

[30] Volkov, A. V., Goldshtein D.V., Shevelev, I.N., Konovalov, N.A., Bol'shakova, G.B., Fathudinov, T.Kh. ... Zelenkov, P.V. (2007). Compression asymmetric static experimental model of degenerative disk diseases. Bull. Exp. Biol. Med., 144(1), 123-125. doi: 10.1007/s10517-007-0270-0

[31]Żurawski, A.Ł., Kiebzak, W.P., Kowalski, I.M., Śliwiński, G., \& Śliwiński, Z. (2020). Evaluation of the association between postural control and sagittal curvature of the spine. PloS One, 15(10), e0241228. https://doi.org/10.1371/ journal.pone.0241228)

\section{МІЖХРЕБЦЕВІ ДИСКИ ПОПЕРЕКОВОГО ВІДДІЛУ ХРЕБТА: МОРФОМЕТРИЧНІ ПАРАМЕТРИ ТА КОЕФІЦІЄНТИ Данилевич В.П., Гумінський Ю.Й., Григор'єва О.А., Данилевич С.Г.}

Важливим елементом доказової медицини є врахування індивідуальної варіативності показників норми міжхребцевих дисків, що беззаперечно $\epsilon$ основою раннього доклінічного виявлення їх патології. Математичне моделювання та комплексна оцінка параметрів міжхребцевих дисків можуть не лише передбачити та визначати ранні прояви патологічних змін, а й допомогти завчасно їх коригувати. Метою дослідження було розрахувати та оцінити мінливість абсолютних, розрахункових та відносних метричних параметрів міжхребцевих дисків в нормі з подальшою можливістю моделювання нормативів на основі індивідуальних лінійних розмірів міжхребцевих дисків поперекового відділу хребта та загальних антропометричних характеристик (довжина та маса тіла, масо-ростовий коефіцієнт та індекс) у юнаків та чоловіків першого періоду зрілого віку (17-28 років), як у окремих вікових групах, так і у об'єднаній групі. На серії MPT-томограм, отриманих на сканері Phillips Achieva 1,5T, вимірювали передній, середній та задній вертикальні розміри, максимальний сагітальний та фрронтальний розміри міжхребцевих дисків L1-L2, L2-L3, L3-L4, L4-L5 сегментів хребтового стовпа (IVD $D_{L 1-L 2}$, IVD $\left.D_{L 2-L 3}, I V D_{L 3-L 4}, I V D_{L 4-L 5}\right)$. Вираховували усереднену висоту міжхребцевих дисків, площі поперечного перерізу та об'єми міжхребцевих дисків, а також відносні показники - відношення суми сагітального і поперечного розмірів, суми трьох розмірів, площі поперечного перерізу та об'єму міжхребцевих дисків до усередненої висоти міжхребцевого диску. Статистичний аналіз отриманих морфометричних показників виконували у ліцензійному пакеті "STATISTICA 6.1". Оцінювали розподіл показників варіаційного ряду, їх середні значення та стандартні помилки, коефіцієнти варіації та асиметрії. Визначили, що суми поперечного $і$ сагітального розмірів та суми трьох розмірів пропорційно зростають у каудальному напрямку, мають розподіл показників максимально наближений до нормального, а їх коефіцієнти варіації у рази менші, ніж для показників площ поперечного перерізу та об'ємів. Показники співвідношень суми сагітального та поперечного розміру і суми трьох розмірів до усередненої висоти міжхребцевих дисків мають варіабельність менше 10\% та відповідають характеристикам генеральної сукупності. Маса та довжина тіла мають значимо вищі коефіцієнти кореляції з сумами сагітального та поперечного розмірів, сумами трьох розмірів та площами поперечних перерізів, аніж з парціальними розмірами міжхребцевих дисків.

Keywords: міжхребцевий диск, поперековий відділ хребта, норма, соматометрія, юнаки, чоловіки першого періоду зрілого віку. 